Breaking Ranks 
This page intentionally left blank 


\section{Breaking Ranks}

I R A Q V E T ERA N S S P E A K O U T A G A I N S T T E WA R

Matthew Gutmann and

Catherine Lutz

甲ㅜ

UNIVERSITY OF CALIFORNIA PRESS

Berkeley Los Angeles London 
University of California Press, one of the most distinguished university presses in the United States, enriches lives around the world by advancing scholarship in the humanities, social sciences, and natural sciences. Its activities are supported by the UC Press Foundation and by philanthropic contributions from individuals and institutions. For more information, visit www.ucpress.edu.

University of California Press

Berkeley and Los Angeles, California

University of California Press, Ltd.

London, England

(C) 2010 by The Regents of the University of California

Library of Congress Cataloging-in-Publication Data

Gutmann, Matthew C., 1953-.

Breaking ranks : Iraq veterans speak out against the war / Matthew

Gutmann and Catherine Lutz.

p. $\mathrm{cm}$.

Includes bibliographical references and index.

ISBN 978-0-520-26637-7 (cloth : alk. paper)

ISBN 978-0-520-26638-4 (pbk. : alk. paper)

1. Iraq War, 2003-Protest movements-United States. 2. VeteransUnited States-Political activity. I. Lutz, Catherine. II. Title.

DS79.764.U6G88 2010

$956.7044^{\prime} 31-\mathrm{dc} 22$

2009035375

Manufactured in the United States of America

$\begin{array}{llllllllll}19 & 18 & 17 & 16 & 15 & 14 & 13 & 12 & 11 & 10\end{array}$

$\begin{array}{llllllllll}10 & 9 & 8 & 7 & 6 & 5 & 4 & 3 & 2 & 1\end{array}$

This book is printed on Cascades Enviro 100, a 100\% post consumer waste, recycled, de-inked fiber. FSC recycled certified and processed chlorine free. It is acid free, Ecologo certified, and manufactured by BioGas energy. 